\title{
Modsatningsfyldte billeder af politik - belyst gennem yngre ufaglærte kvinder
}

Af Pernille Tanggaard Andersen

Hvordan tenkes, erfares og praktiseres politik $i$ forbold til fagforeningen? Hvordan definever og afgranser gruppen af yngre ufaglarte kvinder 'det politiske'? Og hvordan er yngre ufaglarte kvinders situation $i$ relation til medborgerskab, inklusion og eksklusion?

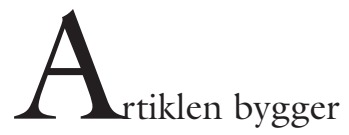

på empiriske analyser fra mit ph.d.-studie, som endnu ikke er afsluttet. ${ }^{1}$ Omdrejningspunktet for Ph.d.-projektet og denne artikel er de yngre ufaglærte kvinders relation til fagforeningen KAD (Kvindeligt Arbejderforbund). En af grundantagelserne bag projektet har været, at de yngre ufaglærte kvinder står i et spændingsfelt mellem dels opfattelser, forstålsesrammer og normer knyttet til traditionalitet. ${ }^{2}$ Det vil her ofte betyde en mere traditionel lønarbejderlivsstil, faste mønstre for prioritering af arbejdsliv, familie og mere fastlagte relationer til 'det politiske'. Og dels er de yngre voksne kvinder bærere af fortællingen om (sen)moderniteten i og med, at de er vokset op under de forskellige indflydelser, der i vid udstrækning både eksisterer som metafortælling og som realitet.

Analysen bygger på interviews med tolv kvinder, der er ufaglærte industriarbejdere og medlem af KAD. Halvdelen af kvinderne er mellem 20-30 år og de resterende er 
mellem 30-38 år. Ses der på civilstand og andre formelle karakteristika, har otte af kvinderne to børn eller flere. Fire af interviewpersonerne er p.t. tillidskvinder og to kvinder har en anden etnisk baggrund. ${ }^{3} \mathrm{Al}-$ le lever $\mathrm{i}$ et heterogent forhold og hovedparten af dem er gift. Alle kvinder arbejder indenfor KAD-industri og er tilknyttet tre højteknologiske fabrikker placeret i henholdsvis København og Roskilde Amt. ${ }^{4}$

Det empiriske materiale bygger på individuelle interviews, hvor der fortælles om arbejdsliv, hverdagsliv, det faglige fællesskab, uddannelse og opvækst, om drømme og forventninger til livet, samt opfattelser af solidaritet og kønsrelationer. Politisk tilhørsforhold tages ikke op som et specifikt tema, men politiske aspekter bliver berørt flere gange i løbet af samtalerne om opfattelser af frellesskaber og fagforeningen KAD. Min tilgang til interview som metode er inspireret af Jane Lave (1991) og Patti Lather (1991, 1997). ${ }^{5}$ Jeg vil først indkredse de centrale teoretiske begreber; 'det politiske' og medborgerskab i sammenhæng med den teoretiske debat om senmodernitet, fordi de udgør en forståelsesramme for gennemgangen af interviewene.

\section{HVAD ER POLITIK OG \\ MEDBORGERSKAB?}

I politologien har der været en omfattende debat, om hvordan begrebet politik skal defineres i forhold til det moderne samfund. Der har grundlæggende været to forskellige modeller, hvorudfra begrebet politik er blevet defineret, 'den statscentrerede model' og 'den samfundsorienterede model' (Thomsen 1997). Indenfor feministisk forskning har opfattelsen af politik i relation til den snævre 'stats-centrerede model' stået for skud. ${ }^{6}$ Argumentet har blandt andet været, at opbygningen og struktureringen i det politiske system har hvilet på skillelinien mellem offentlig og privat, hvilket reelt har været et magtfuldt princip for eksklusion af mange kvinder (Pateman 1988, 1989). Når det gælder feministisk forskning har særligt to teoretiske skoler inspireret opfattelser og definitioner af politik. Antonio Gramsci (1891-1937) fremhæver i sine studier, at civilsamfundet ligeledes er et sted, hvor magtstrukturer er placeret. I Gramscis definition tænkes det politiske bredere og han argumenterer for, at mange emner, der ikke direkte er rettet mod produktion har relevans $(1972,1991)$. En anden væsentlig inspirationskilde for feministernes tilgang til politik er Michel Foucault (1926-1984). Magten i samfundet er ikke en substans, et forhold som kan besiddes, uddeles, afgives eller mestres, men noget som udøves i relationerne mellem mennesker (Foucault 1980). Magten kan ikke lokaliseres hos eller isoleres til institutionelle organer, men er allestedsnærværende. 'Det politiske' bliver i denne sammenhæng, hvordan individer og grupper reproducerer, samt ændrer eller forhandler diskursiv og social praksis. Ingen kan melde sig ud af forhandlingerne i socialiteten og i relation hertil, er alle politiske (Bendix 1999).7 Politikbegrebet rummer således to dele; dels kampen om fordeling af status, værdier og goderne, som foregår på alle samfundsplaner og dels om muligheder og indflydelse på egen livssituation.

Et vigtigt aspekt af 'det politiske' er muligheder for deltagelse og for at gøre sin indflydelse gældende. Medbogerskab handler i idealet om et aktivt og ligeværdigt forhold imellem borgerne i fællesskabet og $\mathrm{i}$ relation til de politiske institutioner og det offentlige liv (Andersen mfl. 1993). Medborgerskab omhandler to dimensioner; dels fælles rettigheder og forpligtelser i et demokratisk fællesskab og dels fællesskabet mellem borgerne i samfundet. De to niveauer i medborgerskabet betegnes som den vertikale og horisontale dimension. Medborgerskabsbegrebet er tæt knyttet til ideerne om 'education of citizenship' og hænger sammen med politisk læring og politisk deltagelse. Målet med politisk læring og aktiv deltagelse er at give alle borgere 
fulde muligheder for at påvirke de politiske, sociale og økonomiske forhold. Det er i relation hertil det engelske begreb 'empowerment' skal ses. ${ }^{8}$ I dansk kontekst er det aktive medborgerskab, det vil sige samspil mellem sociale og politiske rettigheder og medborgernes deltagelse og indflydelse, blevet vægtet højt i den demokratiske opbygning (Siim 1998, 167).

Idealet om aktivt medbogerskab er forholdsvis abstrakt og kan synes langt væk fra marginaliserede gruppers rækkevidde. I en konkretisering af, hvad medborgerskabet betyder vil jeg inddrage B. Turners begrebsapparat. Turner (1992) har lanceret en dynamisk model til at forstå medborgerskabets historiske udvikling og institutionalisering. Tuner opererer med to forskellige dimensioner i modellen for medborgerskab; dels samspillet mellem borgerne og de politiske institutioner og dels samspillet mellem det offentlige og private. Første dimension betegnes aktiv/passiv og knytter an til borgernes deltagelse i de politiske institutioner og fællesskaber og den anden dimension offentlig/privat knytter an til, hvorvidt medborgerskabets kerne forbindes med den offentlige eller private sfære (Siim 1998). Selvom skillelinien offentlig/privat udtrykker en politisk handling, har jeg valgt at inddrage grundideen i Turners model i den videre forståelse og analyse af begrebet medborgerskab.

\section{SENMODERNITET OG}

\section{BESTEMMELSE AF POLITIK}

Det hævdes fra forskellig side, Bauman (1995) Beck (1994, 1992), Giddens (1994, 1991) og Bradley (1996), at der er sket en ændring i samfundsprocesserne. Det hævdes, at udviklingen har bevæget sig væk fra det traditionelle industrisamfund over mod det multikomplekse service-, informations-, og teknologisamfund. De gennemgående elementer i transformationsprocesserne er værdipluralisme, stigende refleksivitet, 'normen om individualisering' og ambivalens. Alle elementer synes at udfordre flere af de eksisterende forståelsesrammer, hvor ud fra politik struktureres, tænkes og forhandles. Min antagelse er i denne sammenhæng inspireret af Anthony Giddens, Ulrick Beck, og Chantal Mouffe. Ændringerne fra emancipatorisk politikforståelse til livspolitik vil forskyde interesse- og politiksfæren således, at fokus rettes på hverdagen, de nære ting og mod bredere sammenhænge end de parlamentariske og traditionelle kanaler som for eksempel et fagforeningsfællesskab. 9

Emancipatorisk politik er blevet kaldt for forudsætningspolitikken og er med til at skabe mulighed for individets autonomi og selvmynddiggørelse (Christensen 1997, 248). Livspolitik kan defineres som en politik, der først og fremmest er rettet på selvrealisering (Giddens 1991). Hvor den emancipatoriske politik er rettet mod at skabe livsmuligheder, er livspolitik mere en form for livsstil (Giddens 1994, 15). Livspolitik er tæe forbundet til det Beck kalder subpolitik. Subpolitik er kendetegnet ved at foregå udenfor de etablerede kanaler, er rettet mod enkelt sager og hvor politiske handlinger i lige så høj grad tager sit udspring $\mathrm{i}$ individuelle som i kollektive krav (1994, 22-23). Det er blevet fremført, at senmoderniteten kun vil influere på de mere velståendes livssituation, men Mouffe hævder, at det også vil ændre på arbejderklassens livssituation. Hun argumenterer for, at arbejderklassen er præget af flere forskellige sociale relationer, og derfor er den enkelte ikke længere så afhængig af hendes/hans placering i produktionsprocessen (Mouffe 1997, 155). De sociale politiske kampe kæmpes mere på tværs af hidtidige struktureringer og i langt højere grad i det, der betegnes som 'civilsamfundet'. ${ }^{10}$

Kritikken fra de engelske teoretikere er overbevisende. Der er behov for at anskue det politiske i lyset af det personlige liv og i forhold til andre platforme end det korporative demokratis kanaler. Dermed ikke sagt, at emancipatorisk politikorientering 
nødvendigvis har udspillet sin rolle, for selvom metafortælling senmodernitet beretter om frisættelse, er der fortsat dominansforhold og kampe der kæmpes. Konsekvensen af en udvikling i retning af livspolitik og subpolitik er, at det kan medføre et mere fragmenteret med-
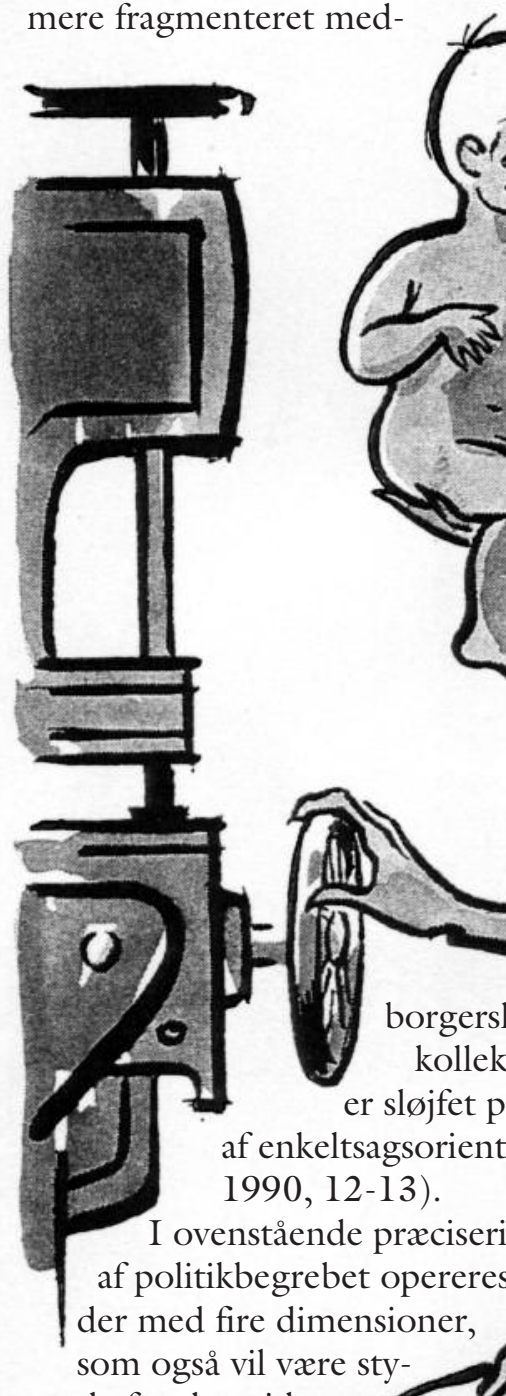

rende for den videre

gennemgang:

Politisk deltagelse

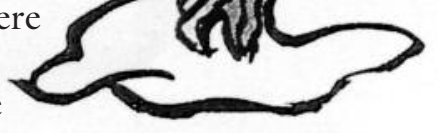

i forhold til fællesskaber, opfattelser af de demokratiske institutioner og opfattelser af politik i relation til 'idealtyperne' emancipatorisk eller livspolitisk orientering. De fire dimensioner vil her blive analyseret udfra optikken opfattelser og praksis knyttet til det faglige frllesskab og institutionen

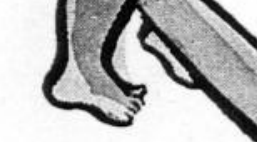

KAD. I nedenstående præsentation og analyse vil jeg for det første se på, hvad der kendetegner de yngre ufaglærte kvinders opvækst, produktionsforhold, og på hvilke opfattelser, der eksisterer om arbejdslivet. Det gør jeg for at indkredse konteksten nxrmere. For det) andet er det hensigten nærmere. For det andet er det hensigten
hvilke opfattelser, der in eksisterer om det faglige \& fællesskab, institutionen
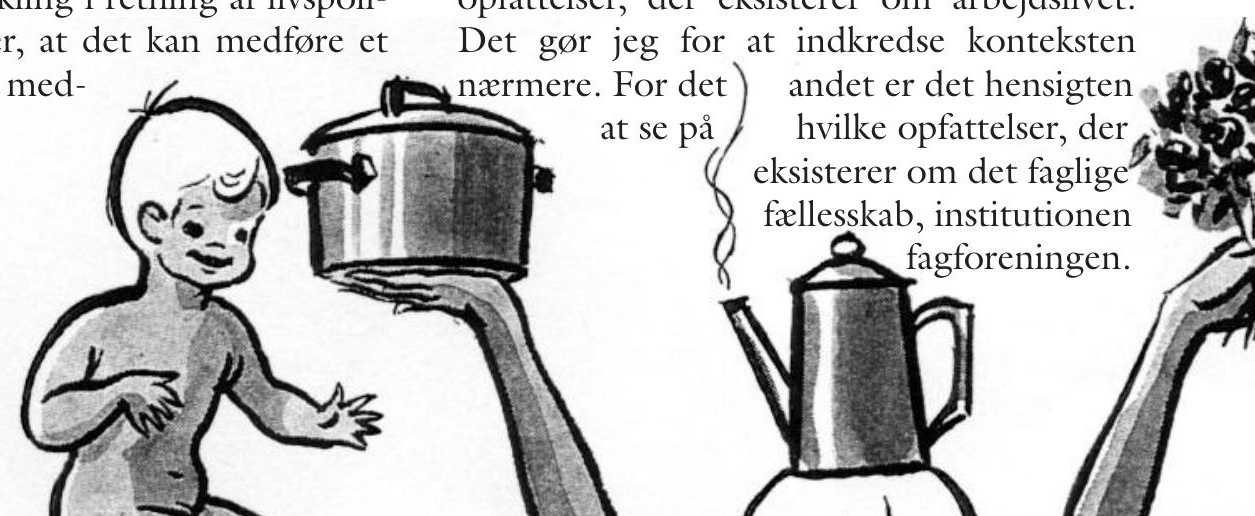
ring). En udvikling mod et mere fleksibelt arbejdsmarked har forskellige betydninger alt efter om man arbejder øverst eller nederst i arbejdshierarkiet. Når der tales om fleksibilitet i arbejdssituationen, er det værd at være opmærksom på, at en udvikling $\mathrm{i}$ retning af mere numerisk fleksibilitet uden funktionel fleksibilitet betyder et hårdt arbejdsliv, som kan indebære, at den enkelte ryger ind og ud af ansættelserne. Et fleksibelt arbejdsmarked har altså et janushoved, fordi øget fleksibilitet kan påvirke de sociale relationer på arbejdspladsen i negativ retning. Dels kan det skabe nye interessekonflikter mellem arbejdsgrupper, og dels kan det betyde et mere specialiseret og autonomt arbejdsliv, hvor der er mindre kontinuitet $\mathrm{i}$ arbejdslivet, og hvor den enkelte kan komme til at stå mere alene.

\section{DET 'HARMONISKE' ARBEJDSLIV}

I kvindernes fortællinger er tilknytningen til arbejdslivet vigtig, fordi det bryder med rollen som kun mor, giver følelsen af selvværd, giver identitet omkring et fagligt 'jeg' og nok så vigtigt en økonomisk uafhængighed. I indkredsningen af det faglige fællesskab spørges der ind til konflikter på arbejdspladsen både mellem de ufaglærte, de faglærte og ledelsen, men det emne synes ikke interessant eller tilladeligt at gå nærmere ind på. Arbejdslivet beskrives som harmonisk og som et sted, hvor der eksisterer stor tolerance. Til at illustrere det harmoniske arbejdsliv har jeg valgt to citater. I det første spørges der til sammenholdet på arbejdspladsen og den faglige aktivitet, og en yngre kvinde siger: "Altså til de der KAD-møder, da er der ikke så stor opbakning, men det er også fordi folk er trætte. De har måske været tidligt oppe og så smutter de efter arbejdstid". En anden siger, at hun ikke oplever nogle hierarkier på arbejdspladsen. Når blikket rettes på forholdet mellem arbejdere og ledelse, siger en tillidskvinde: "Vores forhold til ledelsen er godt, og dem kan man også godt tage no- get pis på, man kan altid komme til dem, hvis det er, og det er ikke sådan, at de lukker døren, og siger, jamen, du er bare arbejder, jeg er direktør". I kvindernes fortællinger er der stor konsensus om, at 'vi har det godt' og 'her er ingen konflikter'. I flere af de yngre kvinders fortællinger er det vigtigt at sige, at hierarkierne er nedbrudt, og derfor synes det som om det harmoniske og konfliktløse arbejdsrum italesættes på de tre virksomheder. Det synes dog anderledes i relation til tale om praksis internt mellem arbejdskollegerne på arbejdspladsen. Her fortælles, hvordan det gælder om at indordne sig og ikke stikke næsen for langt frem.

\section{DET PAPIRTYNDE FAGLIGE FÆLLESSKAB}

Kvindeligt Arbejderforbund er en af de gamle fagforeninger i Danmark. For specielt KAD har det siden dannelsen i 1901 drejet sig om at sikre de ufaglærte kvinders interesser og solidariteten blev skabt ved den særlige organisering af ufaglærte kvinder. Rygraden i opbygningen og organiseringen af den faglige aktivitet har været gennem tillidsfolkene (Weber mfl. 1997). På de tre højteknologiske virksomheder har det været svært at hverve tillidskvinder. Produktionerne kører hele døgnet med tre skiftehold, og efterhånden er der en tillidskvinde knyttet til hver arbejdshold. Det er svært at mobilisere tillidskvinder, fordi det kræver ekstra indsats udover arbejdstiden, og fordi det er en svær position. En tillidskvinde siger: "Det sværeste er at varetage begges interesser ... man er forbindelsesleddet og man ønsker ikke at være "firmaets mand'”. På den ene virksomhed hersker ånden 'du skal ikke tro du er noget', og her ses det nærmest som degraderende, hvis en kvinde påtager sig hvervet som tillidskvinde, for så stikker man jo næsen frem! At hun selv og andre kalder hende 'tillidspige' synes på samme måde at underbygge underordningen; at hvervet ikke er noget særligt, mere noget pigeagtigt end noget en 
voksen kvinde ville påtage sig. Og det til trods for, at tillidshvervet konkret kan give kvinderne mulighed for et mere vekslende og udfordrende arbejdsliv. I kvindernes fortællinger er tillidshvervet ikke en nem post at administrere, både fordi konfliktlinierne virker mere slørede, på grund af nye produktionsorganisatoriske tiltag, og fordi der ofte mangler et solidt fagligt fællesskab, som kan bakke op om de faglige disponeringer. Ses der generelt på kvindernes prioriteringer af den faglige indsats $\mathrm{i}$ arbejdslivet, afspejler analysen her undersøgelsen fra SFI af Csonka (2000). Der er noget som tyder på, at øget fleksibilitet for de lavtuddannede kvindernes vedkommende ikke bliver benyttet til faglige gøremål, fordi de ofte befinder sig i et krydspres mellem arbejdslivets krav og ansvarsforpligtelser i relation til familielivet. Der er blandt de yngre kvinder enighed om, at fagforeningen er en god ven i nøden, men der eksisterer ikke på daglig basis en høj grad af solidarisk støtte og opbakning til de faglige aktiviteter.

\section{"KAD ER ET SIKKERHEDSNET \\ - HVIS VI BLIVER ARBEJDSLØSE”}

Fagforeningen KAD opfattes primært som en nødvendighed, der i krisesituationen kan give den enkelte kvinde sikkerhed og garanterer rimelige arbejdsvilkår. I flere af udtalelserne kædes medlemsskabet af fagforeningen og A-kassen sammen og konsekvensen er, at fagforeningsmedlemsskabet opfattes som sikkerhedsnet i fald den enkelte kvinde bliver arbejdsløs. Fagforeningsmedlemsskabet kædes også sammen med andre forhold af kritisk karakter. Til at illustrere spændingsfelterne har jeg valgt to af de gennemgående negative fortællinger: Fagforeningsmedlemsskabet er dels for dyrt og dels har flere af kvinderne svært ved at se, hvad de får ud af medlemsskabet. Afmagtsfølelsen er derfor tilstede i flere af kvindernes fortællinger og kommer til udtryk i irritation og ligegyldighed overfor det faglige arbejde. I enkelte udtalelser kædes kategorierne fagforening, socialdemokrati og pamperi sammen: "Jeg er træet af socialdemokratiet, der er så mange penge, der går op i administration, der går op $\mathrm{i}$ store middage og jeg har det sådan lidt, at sådan er LO, der er for meget administration”. Langt de fleste yngre kvinder udtrykker således en distinktion mellem de faglige aktiviteter på arbejdspladsen og fagforeningen som institution, og generelt er det fagforeningen som institution, der tages afstand fra. Kritikken, mod fagforeningen som institution, går primært på manglende resultater og manglende lydhørhed.

Som tidligere nævnt medfører arbejdslivets strukturering og praksis ikke udtalte konflikter, og i det hele taget er kvindernes udtalelser med til at illustrere, at fokus for 'politisk kamp' enten er flyttet til andre arenaer, eller er mere usynlig på de tre højteknologiske arbejdspladser. Der er noget som tyder på, at det faglige fællesskab, symboliseret ved fagforeningen, kommer til at fremstå som modstridende til den fælles virksomhedskultur, hvor fokus i langt højere grad er på den enkeltes dagligdag og arbejdssituation. Skarpt sat op virker virksomhedsfællesskabet mere nærværende og 'nødvendigt' end aktiv indsats i det faglige fællesskab, som kan, hvis det er nødvendigt, mobiliseres i krisesituationen. Der er sandsynlighed for, at virksomhedenskulturen er med til at lancere en nødvendighedsdimension i retning af: 'Vi må stå sammen for at overleve og alle må gøre en indsats'. En strategi der i større grad er i stand til at mobilisere arbejdernes engagement i retning af en fælles enhed, for vi må stå sammen mod markedets konkurrence. Analyserne på baggrund af dette studie peger i retning af, at det homogene ideelle værdifællesskab mellem arbejderne er afløst af større heterogenitet og udskiftelighed på arbejdspladserne. Dagligdagen på de tre virksomheder er i stigende grad præget af mindre kontinuitet og mere specialisering $i$ produktionen, og det kan betyde manglen- 
de synliggørelse af et fælles udgangspunkt og i sidste instans påvirke betingelserne for dannelse af og aktivitet $i$ et fagligt fællesskab. Måske kan disse forhold relateres til opfattelsen af, at fagforeningen primært anskues som en institution, et sikkerhedsnet, fremfor et fagligt fællesskab om et kollektivt anliggende.

\section{Mulige INTERESSEFÆLLESSKABER}

\section{Konsdimension}

KAD er unik ved, at det er et af de få selvstændige kvindeforbund i verden. Enkelte af de yngre ufaglærte kvinder peger på, at kvinders livssituation er anderledes end mænds: "Jeg synes ikke KAD og SID skal lægges sammen, for der er forskel på kønnene, og man har jo hver sine behov". Hovedparten af kvinderne er dog ambivalente i forhold til berettigelse af et selvstændigt kvindeforbund og i forhold til kønskategorien. Dobbelttydighederne kommer frem på flere planer. Spørgsmålet om undertrykkelse på et kønssegregerende arbejdsmarked nævnes stort set ikke, men ligestillingen mellem kønnene gør: “Man er jo så ligestillet efterhånden ... jeg har ikke været ude i situationen, hvor det (køn) gør en forskel". En anden understøtter ved at inddrage sine forældres arbejdsdeling "Det er ikke kun mig, der skal vaske op eller tørre den lille i røven, der er ikke den forskel, ... [før var] der rimelig stor forskel, mor stod for hjemmet, men det vil jeg bare ikke være med til". Fortxllingerne er med til at underbygge, at kvindernes udsagn kan være præget af en ligestillingsdiskurs, som indebærer at eventuel underordningspraksis nedtones, for vi har jo opnået ligestilling, og hvorfor skal køn så igen være på dagsordenen! Flere af kvinderne peger på, at en sammenlægning af KAD og SID vil give en stærkere enhed. Kvindernes arbejdsmæssige vilkår sættes i disse udtalelser lige med mændenes. Til gengxld vægter andre af de yngre kvinder, at der er en 'biologisk' forskel som gør, at kvinden tager familieansvaret på sig. I forhold til familievenlige ordninger repræsenterer disse kvinder en tiltro til, at KAD kan varetage deres interesser bedre end SID. En yngre kvinde siger: "At kæmpe for at man skal have fri på barnets første sygedag, det er jeg ikke sikker på, at mandsdominerede forbund ville kæmpe for, så det drejer sig om at kæmpe for kvinders vilkår". Generelt set peger kvindernes udtalelser i retning af, at man på de tre virksomheder er sporet ind på at italesætte enshed mellem medarbejderne og ledelse fremfor forskellighed, som primært udtrykkes i forhold til livet udenfor og andre kvinder. De kønsopfattelser der kommer til udtryk i kvindernes fortællinger, har primært noget med 'biologi’ at gøre. På trods af at de konkret oplever, hvordan oppositionsparrene maskulint og feminint formes gennem den sociale og diskursive praksis, når det gælder forhandlinger om kønsarbejdsdeling i hjemmet og på arbejdspladsen, er det ikke et forhold, som ser ud til at mobilisere. Der er altså noget som tyder på, at kønnet ikke ubetinget er en mobiliseringsstrategi i den faglige profilering af KAD. Ligeledes er der heller ikke fuld opbakning bag opfattelsen af fælles 'kvindelighed' eller fælles interesser, hvilket kan hænge sammen med, at diskursen 'opnået ligestilling' er italesat blandt de yngre kvinder.

\section{Klassedimension}

Kvinderne har ikke kun påtaget sig det ufaglærte arbejde på grund af 'nød', men fordi de ønsker en faglig udfoldelse og et fagligt jeg. Problemerne med manglende selvfølelse kommer ikke så meget fra kvinderne selv, men er en del af spillet om anerkendelses dialektik. ${ }^{14}$ Status og selvværd i relation til arbejdet må i lige så høj grad ses i lyset af placering i arbejdshierarkier, og i relation til forestillinger og fordomme som de yngre kvinder møder blandt andre mennesker. På trods af, at nye tiltag i produktionen er med til at opløse hidtidige struktureringer, er der på disse tre virksomheder stadig stærke uudtalte faggrænser mellem 
den ufaglærte, driftoperatørerne og teknikkerne (ofte mænd der er medlem af SID). Det er dog ikke kun internt, men også eksternt, at de arbejdsmæssige opdelinger bliver styrende for mødet i interaktionen. En yngre kvinde siger om deltagelse i private selskaber. "Siger man, at man arbejder på fabrik, siger de ikke noget tilbage, fordi de ikke synes, det er interessant, men hvis man fortæller, jeg er driftsoperatør og arbejder på ... så kører samtalen”. Det gennemgående træk i fortællingerne er dog, at oplevelsen af lavere status $i$ andres øjne er tys-tys og ikke noget, der tales med kollegerne om. Stigmatiseringen opfattes som individuelt fremfor et fælles materielt og symbolsk vilkår. Selvom flere af kvinderne giver udtryk for, at de oplever andre menneskers positionering af dem i lyset af deres erhverv, er det ikke med til at afføde en fælles mobilisering. Dette kan hænge sammen med, at 'individualiseringen som norm' er en af de forandringsprocesser, de yngre kvinder synes at bære $\mathrm{i}$ deres fortællinger. Larsen (2000) påpeger, at den manglende anerkendelse ikke længere opleves som en klassebestemt skæbne, men i stigende grad som ens egen manglende refleksivitet, der ofte begrundes i tilfældigheder. Tendenserne $\mathrm{i}$ retning af selvopfattet individualisering kan derved være med til at sløre hidtidige skel/forskelle, dels på grund af stigende kompleksitet i livet, og dels fordi kampen i stigende grad står om retten til forskellighed. Der kan dog argumenteres for, at klassekonflikten fortsat er til stede på andre betingelser, for eksempel når det gælder om at sidde med ved 'det opdrkkede tagselvbord'. 15 Yderligere lader det til, at den fælles faglige erfaringsdannelse og dannelse af en form for frlles (klasse-) bevidsthed er under pres i relation til de nye tiltag på virksomhederne, og derfor er det heller ikke sandsynligt, at en vægtning af status og klasse vil vinde genhør som politisk mobiliseringsstrategi blandt de yngre ufaglærte kvinder.

\section{SAMMENFATTENDE DISKUSSION OM POLITIK-ORIENTERINGER OG MEDBORGERSKAB}

\section{Snover afgrensning af politik}

Ses der generelt på den position, som gruppen af yngre ufaglærte repræsenterer, er de ikke marginaliseret i forhold til arbejdsmæssig tilknytning, men kvinderne oplever at være del af en meget presset dagligdag, fordi de ved siden af arbejdet har hovedansvaret for familiens ve og vel. Der er ikke (demokrati-) tid, det fornødne overskud eller den fornødne opbakning til at gå aktivt ind i et politisk fællesskab som en fagforening. For kvinderne generelt er fagforeningen mere et individuelt sikkerhedsnet end et kollektivt fællesskab fokuseret på bedre fælles vilkår. Hermed mener jeg, at der ikke er stor opbakning til at gå ind og tage ansvar for fagforeningen som institution. Til gengæld er kvinderne glade for virksomhedsfællesskabet på arbejdspladsen til daglig. Aktivitet og engagement er primært knyttet til livet udenfor arbejdspladsen, for kvinderne er optaget af det lokale liv og af at gøre en særlig insats $i$ den lille og store familie. Det er den private sfære og de nære ting i livet som har interesse. Spørgsmålene er så, om det politiske liv og det faglige arbejde ikke er tillokkende eller statusgivende, og om det virker bindende for den enkelte? Eller om den manglende aktive deltagelse i fagforeningen som institution snarere hænger sammen med en nyorientering af politik? Endelig, kan den manglende interesse anskues som afmagtsfølelse overfor politik i en institution som fagforeningen KAD?

I afgrænsningen af politik opstilles der en modsætning i kvindernes fortællinger mellem politik i de politiske institutioner og konkrete forhold, der irriterer dem i livet, som kan anskues indenfor den private sfære. Flere af de yngre kvinder er derved med til at afgrænse selve 'det politiske' som langt fra dem selv. Når der spørgers ind til politik og politisk tilhørsforhold er fortællingerne præget af kommentarer, som "[jeg] mangler viden om politik" eller "det interesser 
mig ikke" eller "det lader jeg andre om" eller "jeg forstår ikke, hvad de siger, men jeg prøver at se nyhederne, men har ikke altid tid og kræfter til det". Det politiske bliver defineret som: Det institutionelle, det komplekse, det nationale, det sprogligt uforståelige - alt det som ikke er til at gennemskue eller overskue. Fortællingerne afspejler, at der er enighed om, at man bør følge med, men det virker uoverskueligt, og i langt de fleste tilfælde mangler kvinderne den fornødne energi. Kvinderne italesætter derved 'det politiske' som noget fjernt og klart afgrænset fra deres hverdag på arbejdspladsen. Grundopfattelsen i definitionen af 'det politiske' kan overføres til forståelsen af fagforeningen som institution, der på samme måde virker kompliceret og langt fra den enkelte kvindes daglige arbejdsdag. De yngre kvinders generelle opfattelse af politik slår derved igennem i deres relation til fagforeningen som politisk institution. Hovedparten af kvinderne viser ikke stor interesse $i$ at deltage aktivt for at forbedre det fælles arbejdsvilkår, og det er ikke fordi de ikke værdsætter det daglige arbejdsfællesskab, men dette må ses i sammenhæng med, at de primært anskuer fagforeningen som en individuel sikring.

\section{Inklusion versus eksklusion}

De yngre ufaglærte kvinder synes at repræsentere en gruppe, der på den ene side er præget af en afmagtsfølelse, når det gælder politik, og på den anden side er deres kommunikerede forsvar, at de selv har fravalgt aktiv deltagelse i de politiske institutioner som for eksempel en fagforening. I forlængelse heraf kan der argumenteres for, at den manglende deltagelse og interesse skyldes, at de politiske institutioner ikke formår at inkludere gruppen. Forklaringen er dog langt fra dækkende, for et eller andet sted hænger det også sammen med kvindernes egen afstandtagen til den instrumentelle deltagelsesform. Man kan i denne forbindelse spørge om de politiske institutioner er gearet til at inkludere de former for politikopfattelser, som de yngre kvinder repræsenterer? Ses der på fagbevægelsen generelt har det ideelle endemål været at frigøre mennesker. Der kan dog argumenteres for, at i takt med at fortællingen om (og realiteten af) frisættelsen har vundet indpas blandt medlemmerne, synes opbakningen og nødvendigheden af dens virke ikke længere så central.

Interviewmaterialet viser, at gruppens politikorientering må findes ved at tænke i bredere kategorier. Gruppen af yngre kvinder er nemlig ikke bare magtesløse, når det gælder politik, men synes at gå i retning af nye orienteringer. Politik opfattes ikke i relation til kollektiv aktion og indflydelse institutionelt, men er snarere specificeret ned til ens egen selvrealisering, det nære, det private rum. Det er ikke fordi de yngre kvinder ikke har noget at klage over i deres liv, men de problemer, de har, ses ikke som et kollektivt anliggende. Engagementet i tilværelsen er rettet mod organisering af 'det hele liv', faglig service for den enkelte og på enkeltsager, for eksempel den nye sportshal eller udvidelse af daginstitutionernes åbningstider. ${ }^{16}$ Denne orientering kan tolkes i retning af et livspolitisk element. Der er med andre ord, noget som tyder på, at de yngre ufaglærte kvinders inklusion skal ske gennem dialog med mere livspolitiske og subpolitiske orienteringer; hvor hverdagen, det private, retten til selvrealisering, er i højsædet. Spørgsmålet er så, hvordan orienteringen mod livspolitik spiller sammen med den demokratiske strukturering, der findes i fagforeningerne i dag?

\section{Politik-orientering og medborgerskab}

Generelt set repræsenterer de yngre ufaglærte kvinder en gruppe, som ikke deltager aktivt i relation de offentlige politiske fallesskaber og institutioner. Deres engagementet er primært rettet mod den private sfære, mod det nære liv, hvor aktivitet er knyttet til den lille og store familie og fritidsliv i lokalområdet. Sxttes tingene på spidsen, så er denne gruppe af yngre ufaglærte kvinder en del af medborgerskabet formelt set, men det er ikke særligt bevidst- 
gjort i deres tanker og praksis. Med andre ord; de er ikke en del af det 'etablerede medbogerskab', og dermed er der fare for, at gruppen bliver potentielt ekskluderet fra de politiske arenaer. Ses der mere overordnet på udviklingen, er der ellers tale om, at kvinderne i Skandinavien i stigende grad er en del af det inkluderede medborgerskab (Siim 2000, Skjeie 1992), men i forhold til denne analyserede kontekst er virkeligheden stadig en anden. Der er derfor behov for udvikling af de politiske fællesskaber og institutioner, som en fagforening, således, at institutionerne $\mathrm{i}$ stigende grad fanger pluraliteten og de individuelle krav.

\section{Noter}

1. Det samlede materiale er endnu ikke færdigbehandlet og derfor opererer jeg ikke med nogle endegyldige resultater, men artiklen her er del af en dynamisk analyseproces.

2. Tradition kan beskrives som en overlevering af informationer, og i den forstand er traditionalitet graden af optagede overleveringer i konstitutionen af ens livsfortælling. For yderligere præcisering se Calhoun (1993).

3. I denne analyse inddrages etnicitet ikke som analysetema, hvilket er hensigten $i$ afhandlingen. 4. Det har været vigtigt for mig at profilere mig som uafhængig af KAD. Så bortset fra de pilotinterview, som KAD-industris administrative ledelse hjalp med at etablere, er kontakten og formidlingen med kvinderne skabt ved, at jeg har taget kontakt til tillidskvinderne og selv er kommet ud på den pågxldende virksomhed. Andre interview er foretaget hos kvinderne privat.

5. Et interview er en form for praksisfellesskab mellem interviewer og interviewede, der er bundet til en bestemt kontekst. Forforståelser, den diskursive praksis og den sociale kemi spiller ind på de resultater, som kommer til syne. Patti Lather taler om, hvordan forskerens rolle drejer sig om at balancere mellem empati og ikke at havne i autenticitetsfælden. Se for videre beskrivelse Yvonne Mørcks forskerintroduktion til Patti Lather, Kvinder, Køn \& Forskning nr. 1. 2000.

6. Definitionen af politik ud fra den 'statscenterede model' omhandler det privilegium at styre i forhold til staten. Flere og flere analyser forsøger dog at forene de system- og samfundsorienterede perspektiver, så politik tænkes bredere.
7. Socialitet er et begreb der dækker utrolig bredt. Det kan defineres som det sociale eller de andre som individet møder i interaktionen.

8. Begrebet 'empowerment' kan oversættes til dansk, som dels mægtiggørelse, det vil sige udvikling af politiske kompetencer, og dels som myndiggørelse, det vil sige udvikling af demokratiske identiteter (Kristensen 1998, 58-59).

9. Med livspolitik refererer jeg til Giddens definition af politikorientering, som skabes i selvartikulationen i en posttraditionel kontekst, hvor arenaen for den politiske ageren er global.

10. Civilsamfundet kan karakteriseres som en bred vifte af borgere, med vidt forskellige kulturelle og sociale identiteter, og her som på andre niveauer i samfundet, er kvinders erfaringer og interesser ikke nødvendigvis fælles.

11. I begyndelsen af 1900tallet var dette organisationsprincip fremherskende. Frederick W. Taylor. lancerede organisationsteknologien, som kaldes Scientific Management. En grundregel var at opdele arbejdsopgaver i simple arbejdsgange og i Taylorismen er den numeriske fleksibilitet prioriteret over andre former for fleksibilitet.

12. Numerisk fleksibilitet betyder, at arbejdsstyrken skal tilpasse sig alle ændringer i produktionen. Med funktionel fleksibilitet menes, villigheden til at påtage sig skiftende arbejdsopgaver og kunne indgå i forskellige teams (se Bjerring 1999).

13. Specialiseringen i 'selvstyrende grupper' har forskellige betydninger i mine analyser for de ansatte på de tre virksomheder. For det første indebærer det større selvbestemmelse af arbejdsindhold. For det andet forventes det, at den enkelte kan indgå i et team, og for det tredje kan det ændre på betingelserne for det faglige fallesskab, fordi hver gruppe i vid udstrækning passer sit i løbet af arbejdsdagen. 14. Den filosofiske teori om anerkendelse hævder, at et menneskets selvforståelse afhænger af den måde, det ser andre mennesker på. Gennem læsning af G.W.F Hegel udarbejdede Kojéve forskellige bestemmelser om den menneskelige eksistens. Forholdet til den anden forstås som et dialektisk forhold. Nylæsningen af Hegels Phänomenologies des Geistes (1807), dannede centrum for opfattelsen af anerkendelsens dialektik (Lübcke 1982).

15. Klassekonflikten i dag drejer sig derved om investeringer i de distinktioner, der danner kulturel og symbolsk kapital (se Larsen 2000).

16. Sidstnævnte problem har en emancipatorisk dimension, og er med til at illustrere at politikorienteringer ofte i praksis indeholder både emancipatoriske og livspolitiske elementer. 


\section{LITTERATUR:}

- Andersen, Johannes, Ann-Dorte Christensen, Kamma Langberg, Birte Siim \& Lars Torpe (1993): Medborgerskab. Demokrati og politisk deltagelse. Systime, Herning.

- Bauman, Zygmunt (1995): Life in fragments - essays in postmodern morality. Blackwell Publisher, Oxford.

- Beck, Ulrich, Anthony Giddens \& Scott Lash (1994) (eds.): Reflexive Modernization, Politics, Traditions and Aesthetics in modern Social Order. Polity Press, London.

- Beck, Ulrich (1992) [1986]: Risk Socity. Towards a new modernity. SAGE Publications, London.

- Bendix, Eva (1999): "Fisseflokkens feministiske skridt”, i Kvinder, Kon \& Forskning nr. 4. 1992. - Bjerring, Bodil (1999): Familieorienterede livsformer og arbejdspladsernes fleksibilitetsønsker - nogle udkanterfaringer (under publicering).

- Bradley, Harriet (1996): Fractured identities. Changing patterns of inequeality. Polity Press.

- Christensen, Ann-Dorte (1997): "De politiske kulturelle betydninger af køn”, i Ann-Dorte Christensen, Anna-Birte Ravn og Iris Rittenhofer (red) Det kønnede samfund pp 232-255. Aalborg Universitets forlag.

- Csonka, Agi (2000): Ledelse og arbejde under forandring: om indholdet, udbredelsen og konsekvenserne af fleksible organisationsformer $i$ danske virksomheder. Socialforskningsinstituttet 00:2, København. - Foucault, Michel (1980): Power/Knowledge-Selected Interviews and Other Writings 1972-1977.

Pantheon Books, New York.

- Giddens, Anthony (1991): Modernity and selfidentity. Polity Press.

- Giddens, Anthony (1994) [1991]: Modernitetens konsekvenser. Hans Reitzels Forlag.

- Gramsci, Antonioni (1972): Politik og Kultur (artikler og breve udvalgt af Kjeld Østerling Nielsen). Gyldendal, København.

- Gramsci, Antonioni (1991): Fangselsoptegnelser $i$ udvalg. Museum Tusculanum, København.

- Kristensen, Niels (1998): Skolebestyrelser og demokratisk deltagelse - støvets fortalling. Jurist og Økonomforbundets Forlag.

- Laclau, Ernesto \& Chantal Mouffe (1997): Demokrati og hegemoni. Akademisk Forlag.

- Larsen, Jørgen E. (2000): "Klassebiografi og individuel biografi", i Social Kritik nr. 67, 12. årgang.

- Lather, Patti (1991): Getting Smart. Feminist Research and pedagogy with/in the Postmodern. Routledge, New York.
- Lather, Patti \& Chris Smithies (1997): Troubling the Angels. Women Living with HIV/AIDS Westview Press, Boulder.

- Lave, Jean \& Wenger, Etienne (1991): Situated practice. Perspectives on activity and context. Cambrigde University Press, Cambridge.

- Lübcke, Poul (red.) (1982): Vor tids filosofi-engagement og forståelse. Politisk Forlag.

- Phillips, Anne (1995): The Politics of Presence. Polity Press, London.

- Skjeie, Hege (1992): Den politiske betydning av kjøn. Et studie av norsk topp-politik. Institut for samfundsforskning, 92:11, Oslo.

- Siim, Birte (1998): Det sociale medborgerskab, i Larsen, Jørgen E. \& Iver Horneman Møller (red): Socialpolitik pp 152-172. Munksgaard.

- Siim, Birte (2000): Gender and Citizenship. Politics and Agency in France, Britain and Denmark. Cambridge University Press, Cambridge (in press). - Tanggaard, Pernille (2000): Identitet og arbejdsliv set $i$ lyset af senmoderniteten og fleksibel kapitalisme GEP-tekstserie, Aalborg.

- Thomsen, Jens Peter F. (1997): Moderne politikbegreber introduktion til systemanalyse, marxisme, diskursanalyse. Systime.

- Torpe, Lars (1990): Det demokratiske medborgerskab-fornyelse af en tradition. Institut for Økonomi, Politik og forvaltning. Aalborg Universitet.

- Young, Iris (1990): Justice and the Politcal Difference. Princeton University Press, Princeton.

\section{SUMMARY}

The author offers empirical examples from a study among young unskilled women that are members of KAD. Solidarity was in KAD formed by the special organisation of women. The analysis focuses on the meaning of politics for young unskilled women. And the author shows that perceptions of politics are related to the transformation from emancipation politics to life politics. The concept of politics is directed towards everyday life, the near things instead of the traditional political communities of interest like the union.

Pernille Tanggaard Andersen ph.d-stipendiat ved GEP (Køn, Magt og Politik) $\mathrm{AAU} / \mathrm{KU}$ 